\title{
Christianity, Islam, and Social Revolution in Nigeria
}

\author{
Pius Oyeniran Abioje \\ Ph. D, Department of Religions, University of Ilorin, Ilorin, Nigeria.
}

\begin{abstract}
This article advocates a revolutionary approach to the problem of mass impoverishment in Nigeria. Since such a possibility is remote and forlorn without the unity of ordinary Christians and Muslims who constitute the majority in the country, both Christianity and Islam are traced to their revolutionary conclusions. In other words, the question of compatibility of each of the two religions with revolutionary wisdom is addressed, towards sensitising ordinary Nigerian Christians and Muslims on the sanctity of redemptive revolution. Poverty, hunger, and misery don't distinguish between Christians and Muslims, and those who are colluding in the mass exploitation of ordinary Nigerians are some Christians and Muslims. Unless the mass of ordinary Christians and Muslims unite against their exploiters who use religion as a means of divide and rule, paradigm may never shift in favour of the impoverished majority. The conceptual framework derives from a form of liberation theology that coincides with some (not all of) Marxist revolutionary orientation. It found seeds of revolution in the teaching and practice of both Jesus and Muhammad. It, therefore, calls on ordinary Christians and Muslims in Nigeria to unite and oppose, revolutionarily, mass impoverishment that is based on inhumanity of human beings to human beings.
\end{abstract}

\section{Introduction}

Nigeria is majorly populated by Christians and Muslims. Visible adherents of African Traditional Religion (ATR) are not only in the minority; their presence in government is absolutely insignificant, if it exists at all. The question bothering many concerned persons is: Why is there mass poverty in a land that is flowing with petrol-dollar, other mineral resources, and long stretches of fertile land, under the dominion of some Christian and Muslim rulers? Odumuyiwa (2001) wrote his professorial inaugural lecture on Nigeria as "A Religious but Criminal Society", listing such crimes as "commercialisation of religion, extortion of adherents, religious intolerance, embezzlement of funds, lobbying for posts more-so when people's lives are taken in order to get to the exalted positions in churches, mosques, and shrines." That is incontestable, and no religion is sacrosanct as a human enterprise, but the concern of this study is different. It is about politicisation of religion to attain power and wealth, which is peculiar to the Christians and Muslims who dominate Nigeria politicoeconomically. Tasie (2003) is more apposite here, where he wrote that:

Religion has become an ass over the years, and more so now, particularly for Nigerians with inordinate ambitions and especially the political class. They are the main riders; they ride the religious ass, and manipulate it to suit their own purposes and agenda (often times hidden); and even when they cite the holy books and doctrines (whether it is in crusade, jihad or any other) as they often do, it is more often than not, manipulative.

One would discuss how ordinary Nigerians, who are at the receiving end of religious manipulation, can free themselves from the resultant mass poverty that is the order of the day. Unity, solidarity, globalization or global village, harmony, and so on speak of a value that is indispensable to human progress in a community and society at large. One would think that the myth of the Tower of Babel represents an abuse of human unity, which is better described as conspiracy. While unity is a virtue that is capable of being abused, conspiracy is always a negative terminology. This study addresses the conspiracy of the privileged minority Nigerians who exploit the wealth of the nation and shortchange ordinary Nigerians who constitute the majority, using religion (Christianity and Islam to be precise) as a means of divide and rule. Indubitably, there is a primordial rivalry between Christians and Muslims, since the two proselyte and seek to convert the whole world to their own religions. In the words of a Nigerian Islamic scholar, Bidmos (2006):

Both Islam and Christianity are missionary faiths in which case proselytization is an obligatory duty. To both of them, $D a$ 'wah or Mission must be undertaken as a means of winning more souls to their fold. In the course of this study, my findings show how the mode of conducting Da'wah or Mission (proselytization) has often led to straining the relationship between the two groups.

Rivalry is, of course, a datum in many communities and societies around the world where the two religions exist side-by-side, and Nigeria is one of such societies. Yet, there seems to be no doctrinal backing in either Christianity or Islam for bitter rivalry in propagation of faith; the rationale is to be found in politicisation of religion for politico-economic gains. This study addresses the issue of how both religions support war against injustice. It searches for evidence of approval for confrontational revolution in the life and teaching of Jesus and Muhammad, respectively, which can unite Christians and Muslims in Nigeria to fight the yoke of social injustice that is retarding the country's progress. One is convinced that mass impoverishment will persist as long 
as ordinary Christians and Muslims don't unite against it, revolutionarily. The perpetrators who collude in the act of misappropriation of public wealth are some Christian and Muslim politicians who are dominating the land; the mass of ordinary Christians and Muslims must jettison religious bigotry to struggle to establish social equity and justice, including financial accountability.

\section{Theoretical Framework}

This study is an exercise in liberation theology, done on the platform of Christianity and Islam whose adherents dominate Nigeria's political landscape. The article advances the Marxist theory that a conscious decision by the proletariat to liberate themselves from the clutches of the bourgeoisie is indispensable to social equity (Appadorai, 2004). The relevance of that to the Nigerian context is that ordinary Nigerians, who are suffering from poverty in the midst of abundant resources, including petroleum, should not look-up to religion (any religion) to save them from the greed of the rulers who use religion as a means of divide and rule; they must unite against their exploitation by the religio-political rulers who are united surreptitiously against them. Appadorai further cites Marx as stating that:

Since the establishment of private property, society has been divided into two hostile economic classes. Just as in the ancient world the interest of slave owners was opposed to that of the slaves, and in medieval Europe the interest of the feudal lords was opposed to that of the serfs, so in our own times, the interest of the capitalist class, which derives its income mainly from the ownership of property, is antagonistic to the interest of the proletariat class, which depends for its livelihood chiefly upon the sale of its labour power.

The ordinary Nigerians (i.e. those that can be classified as belonging to the working class, and those who are financially poor, generally speaking, who are not holding any sensitive position of public authority) are represented in the "proletariat" (the wage-earning class), while the dominant religio-political rulers are represented in the "bourgeoisie" (the class of those preoccupied with materialistic pursuits and concerns at the expense of the proletariat). Religion, in its pristine form may not be the "opium of the people", as Marx held, but, it is in the general characteristics of human beings to pervert goodness, and consciousness must not be lost on that score. To a large extent, Marx is right that the mode of production (or wealth) determines the general character of the social, political and spiritual processes of life (Appadorai, 2004). What is more, Sabine and Thorson (1973) also quote both Hegel and Marx as holding that, "the driving force of social change is struggle, and the determining factor in the last resort is power". That has been proven by the various experiences of revolution, starting particularly with the American Revolution, 1775-1788, and the French Revolution, 17891815.

The American Revolution was particularly significant because of its widespread effects. As Smith and Smith (1980) note, "It led to revolts for independence and civil rights throughout Europe; it changed the great nations' attitudes toward their colonies, and England, particularly, began to accept the fact that some day all colonies would be independent." Smith and Smith also note how the American Revolution "had a decisive influence on the French Revolution" that was based purely on civil rights and survived by priests (mainly Catholic priests) who cooperated, while most of those who resisted were exiled and/or killed. All of that goes to show how the dominant class will rarely "give-up comfort and power without severe struggle" (Appadorai, 2004, quoting Marx). What is more, religion has no room in the materialists' scheme, except to be used hypocritically to cow and milk ordinary people (opium), and as a means of divide and rule.

It may not be out of place to say that, at least by some extension, African nationalists who struggled for the independence of African countries from the colonial masters were also beneficiaries of the American example, particularly since most of them were literate and read about the American and European revolutions. Of course some non-literate African rulers resisted the colonialists, as evident in some historical books (e.g. Fajana, 1976), but the issue to be emphasized is that ordinary Nigerians must not allow religion to be used to divide and rule them. Above all other considerations, good governance and pro-people leadership should be the parameter for acceptance or rejection of political leaders.

The example of the African nationalists is apposite, since although they were mostly Christians and Muslims by birth or conversion, they did not allow their religious differences to stand on their way of seeking independence for their countries. Besides, violent resistance was adopted, where they found it inevitable, as in the cases of Kenya and South Africa, for example. One's conviction is that neo-colonialism, which has eroded and is obstructing the expected gains of the independence achieved by the nationalists should be fought without religious but noble considerations. Tasie (2003) notes that:

Religion per se, I am strongly persuaded, does not create problems, particularly the three main religions of Nigeria - Traditional African Religion(s), Christianity and Islam. Each evidently teaches love in its own way and may not discourage peaceful co-existence, mutual respect and tolerance. Whenever we have so-called religious clashes in Nigeria, I would dare to posit that it is either because of bad Christianity and bad Islam, bad Christians and bad Moslems or all of the above. 
That tends to justify the position of this article that neither Christianity, Islam, nor any other religion should be allowed to stand on the way of human solidarity and progress in Nigeria or anywhere else. Above all, the mass of ordinary Nigerians who are at the receiving end of neo-colonialism should unite and adopt a revolutionary approach to undo their marginalization and exploitation. But, is there anything intrinsically opposed to such a revolutionary measure in Christianity and Islam? The attempt to answer that twin question follows in two steps, with the first resting on Christianity. A Christian theologian, Ruiz (1981), speaking positively about Karl Marx, holds that "Class distinctions may disappear and a Communist society may appear? Where is the contradiction with Christianity? Just the opposite: it would be reestablishing contact with the Christianity of the early times, in its purest, most human, most moral aspects." He condemns Christian bourgeois and rich persons who deal with humble people from the attitude of condescension and paternalism, saying they do so insincerely, without any human content. One cannot agree less, and there is no reason to doubt that what Ruiz wrote applies to general human character rather than to a particular religion. That leads this discourse into how Christianity became politicised.

\section{The Politicisation of Christianity}

The religion emanated from the life and teaching of Jesus Christ. He was a Jew, and his religious experience derived from Judaism. O'Hear and Groves (1994) present a simple introduction of him thus:

The man whom we know as Jesus Christ was born during the reign of Augustus, the first Roman Emperor (63 BC - $14 \mathrm{AD})$, around the year $4 \mathrm{BC}$. He was Jewish and brought up in Galilee, though he may not have been born there.

He is popularly known as Jesus of Nazareth. Not too much is known about him, because after age twelve, nothing is recorded about him until he was about thirty years old when he started his prophetic ministry in which he spent about three years and he was crucified. Yet, there is no ambiguity in his prophetic message and amiable personality. Boer (1976) rightly notes that "The message of Jesus is simple", stating further that:

He preached that the kingdom of God was at hand and that men could enter it through repentance and belief in the gospel (Mark 1: 14, 15). The repentance Jesus required was for disobedience of the law of God. This law required men to love God above all and their neighbors (sic) as themselves (Matt. 22: 34-40).

The mission of Jesus was to establish the kingdom (otherwise called the reign) of God on earth through preaching love of God and neighbour. Hence he emphasised love as the supreme law of God and one that summarises the entire divine code. Baker (1998) puts it this way: "Christ summarized our whole duty as to love God with our whole being, and our neighbour as ourself (Mt. 22:34-40)". Konijn (1973) likewise observes that love is the basic norm, and "all other commandments and laws must lead back to it." Yet, as he further notes, it "looks more obvious than it is", since "you won't build a better world just by shouting 'love one another'." Well, all the foregoing summarises and explicates the message of Jesus as the one whose life and teaching Christians are expected to hold as their matrix and cynosure.

Equally significant is the point that Jesus displayed no interest in politics, even though he asked his followers to respect legitimate political authorities, such as when he told his hearers to give to Caesar what belongs to Caesar (Mt. 22: 17). And in another instance he is quoted specifically as saying that his kingdom is not of this world (John 18:36). This indicates that Christianity should not be inextricably bounded up with politics. Crossan (2007) explains how Jesus rules-out all misinterpretation of his apolitical position, when he adds that "if my kingdom were of this world, then would my servants fight, that I should not be delivered up to execution." In his own mind, Crossan could hear Jesus adding:

Your soldiers hold me, Pilate, but my companions will not attack you even to save me from death. Your Roman Empire, Pilate, is based on the injustice of violence, but my divine kingdom is based on the justice of nonviolence.

That is Jesus as perceived scripturally and theologically, as one not given to politics and politicking. For about three centuries after his death, the Christians (the followers of Jesus Christ) could not be categorised as players in any political arena either. But that situation started to change gradually with the conversion of Emperor Constantine in A.D. 313. As Renwick and Harman (2002) note, the Emperor maintained close friendship with the bishops and did his best to settle the various controversies which arose in the Church at that time. But, as they further observe, that imperial intervention in Church affairs constituted a precedence which proved a most serious problem in later ages.

In course of time, politicisation of Christianity got to its climax. By the thirteenth century, as Schreck (1987) notes, hardly anyone believed in religious freedom or toleration, such that persons living in a Catholic state or kingdom were, for instance, expected to believe Catholic teaching, and if they did not, they were viewed as a threat to the society (ditto in Protestant territories). That is the type of situation that is prevalent in Nigeria, where religious favoritism is rife.

A question that must be addressed is whether there is anything in the life of Jesus that can justify use of force or violent resistance against politico-economic injustice perpetrated by politico-religious leaders or by any 
of such authorities or forces. The prevalent image of Jesus is that he is the prince of peace and an icon of pacifism. Craghan (1994) states that:

Pacifism usually means a refusal to resort to arms and to take part in warfare. This course of action generally rests on religious grounds, but not necessarily so. Pacifists often appeal to the writings of the New Testament to find the inspiration for their resistance to violence, especially warfare. Although this appeal is not without its scriptural difficulties, Jesus' forgiveness of enemies, his compassion, and his refusal to defend himself through the use of violence provide the basis for the pacifist course of action.

Beyond that, one can quote Jesus as teaching that "If any one hits you on the right cheek, offer him the other as well; if someone wishes to go to law with you to get your tunic, let him have your cloak as well. And if anyone requires you to go one mile, go two miles with him" (Mt. 5:39-41). Yet, all of that does not seem to exhaust the whole reality of Jesus. Schillebeeckx (1981) links love (otherwise termed charity), which Jesus makes the plank of his doctrine, with political commitment. His syllogism is that, one cannot love God without loving humankind, and loving humankind can only happen in concrete within given socio-political structures; "those structures are unjust to a very great extent, and so not to change the structures is to give-up Christian charity." Consequently, Schillebeeckx sees "no split, and even less opposition, between Christian life and political commitment." What he means by political commitment becomes clear when he adds that "injustices can reach a peak, and have reached the peak in certain countries; in those specific cases I think that, from the point of view of Christian conscience, one can't condemn an option for violence against established violence that can't be defeated by other means." Schillebeeckx might not have spoken for all Christians, but he is not possibly the only one in that school of thought. He has at least spoken the conviction of this researcher.

The issue of justice and Christian conscience is beyond what may be trivialised. The maxim goes that there cannot be peace where there is no justice. Konijn (1973) writes that:

Along with all the emphasis on love goes a rebelliousness aimed at existing laws and structures; so that society comes under attack, amid a general buzz of criticism. That is a good thing, of course, as regards laws and structures which are out of date; which no longer protect and serve the human person but stand in the way of his happiness, whether they exist in the economic sector, in education, in the political sphere or within marriage.

Of course the specific issue of socio-political and economic justice in Nigeria is the focus here. Along the line of Schillebeeckx, Konijn, and other theologians of that ilk, one would think that someone who believes in confrontation on the ground of unjust laws and exploitation may cite the Scripture where Jesus uses the whip to chase-out those buying, selling, and exchanging money in the Temple. It stands written that, "Making a whip out of cord, he drove them all out of the Temple, sheep and cattle as well, scattered their tables over, and said to the dove sellers, 'Take all this out of here and stop using my Father's house as a market'." (John 2: 14-16). That example of Jesus can justify revolution in Nigeria and elsewhere, where the politico-religious rulers perpetrate impoverishment of the ordinary citizens.

The question also arises whether as a Jew, who must have known about the near innumerable wars fought by his people, Jesus could have condemned the idea of a just war. While pacifists can quote him to justify pacifism, they cannot say whether he supported war or not. There is no indication that he objected to war in specific terms, rather in Luke 14:31 he advises on the wisdom of waging war and seeking peace. Theologically speaking, Clouse (1998) writes:

Eusebius wrote about Constantine's campaigns as holy wars. The growth in the church made it difficult to maintain pacifism because Christians were no longer a minority in society. Also the danger posed by the Barbarian invasions made defensive war seem necessary. Augustine led the way in revising Christian attitudes toward war by formulating a series of rules to regulate violence and permit believers to fight for the empire. According to his view, war should have as its goal the establishment of justice and the restoration of peace.

That marks the difference between the theory of pacifism and the reality of war. In Latin America, liberation theology was adopted by many Catholic theologians. Gutierrez (1981) writes of the experience, stating that "at the root of every misery, injustice, alienation, exploitation that we live through in Latin America there is sin, and so, to preach, to announce love is to go to the root of that social evil and this, it seems to me, leads us to an evangelization tremendously committed to the situations in which people live." Obviously, "to go to the root", as Gutierrez states it translates going into confrontation, because those who are at the root of social disequilibrium, those who are feeding fat on injustice are not likely to take-it lying-low. Gutierrez justifies Christian "revolutionary commitment" by saying that faith should not be spoken-of in abstraction, but in relation to people and the reality of their lives. He admitted that liberation theology involves a form of ideologisation of faith, but that it counters the people's exploiters who adopted a Christian ideology that suited their whims and caprices. In the words of another theologian, Casalis (1981), "It is quite normal for those who place themselves on the side of oppressive power to seek in the gospel the justification of their position." Yes, indeed. What is more, liberation theology is applicable not only to Latin America; it is capable of wider application.

The Crusades ("Christian holy wars") also indicate that Christians have long abandoned pacifism in the face of earthly realities. In the words of Renwick and Harman (2002), "The fanaticism of the rough Turkish 
Muslims who captured Jerusalem from the Arabs had become a menace to Christendom, and pilgrims were being seriously interfered with." Yet they and other historians, such as Schreck (1987), note how in the Crusades, Christians fought both just and unjust wars. This researcher is convinced that mass impoverishment may not end in Nigeria until the mass of ordinary Christians and Muslims unite against it, revolutionarily. If the exploiters say, for instance, that Jesus preached pacifism, they should retort that he also used the whip, when he considered it necessary.

\section{The Politicisation of Islam}

The Prophet, through whom Islam was revealed, was born in Mecca, the Quraysh, around A.D. 570, and his name, Muhammad, means "highly praised". He received his calling and commission in approximately 610, to "rise and warn, and glorify thy Lord". Henceforth, as Smith (1991) notes, the Prophet threw his "heart and soul into his preaching, adjuring listeners wherever he could find them to abandon their evil ways and prepare for the day of reckoning." He was resisted by the rulers of the land and skeptics in the first instance. Gradually, some people of substance became convinced of the sense and worth in his message, and his followership grew steadily. Yet, as Smart (1981) has it, the increasingly hostile pressure from those of the Quraysh who opposed him, coupled with the death of his beloved wife, Khadija, made him to think that Mecca did not hold much future for him. He also did not succeed in his effort to establish his faith in Taif. Providentially, as Smart further notes:

Medina, three hundred miles north of Mecca, offered more hope. Some of the Medina citizens, concerned at the internal strife which plagued that city, were attracted to Muhammad as a leader who might bring peace and a re-ordering of the community. In A.D. 622 the Prophet, on the secret invitation of these citizens, migrated to Medina. This migration is known as the Hijrah (or in older transliteration the Hegira). From it the beginning of the Muslim era is dated.

It is not surprising that the people of Medina knew about Muhammad, because, as history has it, his teaching and popularity had spread to a great extent through pilgrims and other visitors to Mecca. At the critical period in which the Meccan rulers were plotting to get rid of him, Yathrib (the current Medinat al-Nabi, the City of the Prophet) was facing internal rivalries and the leading citizens sought for a strong leader from without; they found the required leadership qualities in the Prophet and appealed to him to come and lead them. That was the extent to which he was appreciated outside Mecca. What is more, he did not disappoint those who entrusted the leadership of their sprawling city to him. As Smith (1991) records it:

As chief of state and trustee of the life and liberty of his people, he exercised the justice necessary for order, meting out punishment to those who were guilty. When the injury was toward himself, on the other hand, he was gentle and merciful even to his enemies. In all, the Medinese found him a master whom it was as difficult not to love as not to obey. For he had, as one biographer has written, 'the gift of influencing men, and he had the nobility only to influence for the good'.

It goes without saying that the Prophet was a genuine man of God, going by that historical record. The biographical note informs that politics is not necessarily a dirty game, even though human nature is prone to perversion of goodness. The brief annotation indicates that Islam did not start as a political religion, and so, it should not be said, as the impression is often created in Nigeria, that Islam and politics are inextricably intertwined (Adeniyi 2004, Bidmos 2006). Muhammad's calling to be a city leader seems to be as divine and providential as his calling onto the prophetic Chair. He received his vocation in 610, but he did not become a politico-religious leader until 622. He established the first Muslim theocracy in Medina, but the Qur'an does not seem to indicate that Islam, as an organised religion, cannot survive without theocracy in a religiously pluralistic society, such as Nigeria.

Historically speaking, not long after the Jews settled in the Promised Land, they pressurised their religious leaders that they wanted to have a king to rule them like the other nations known to them. Although as Norman (2004) notes, the emergence of a human king did not, ideally, conflict with the erstwhile theocracy, since a king chosen by God is not expected to be a despot or selfish dictator, but rather one who would walk in the light of the Lord and seek God's guidance in all matters, there is always a gulf between the ideal or theory and human frailty. The Jews knew that they would feel less constraint to confront an erring king than a leader who spoke "on behalf of God". Yes, it can be said that "God said to Moses", but who was there? Skepticism, insincerity, and forthrightness are in the same mixed bag of life. And if one may ask, how many religio-political leaders are as considerate and as selfless as the Prophet Muhammad?

Doctrinally speaking, there seems to be no basis in Islam for attributing to God political rulers who rig themselves into positions of public authority, and are perpetuating corruption and mass misery. Ideally, such rulers should face mass protest and be ejected out-rightly. Yahya (1984) quotes the Qur'an to the effect that:

Permission is given to those against whom war is waged, for they have indeed been wronged, and Allah is certainly capable of giving them support. (They are) those who have been driven out from their homes unjustly, only because they said: 'Our Lord is Allah' (XX11.39). 
the phrase, "for they have indeed been wronged", and the word, "unjustly", in the citation, appear applicable in all unjust circumstances. The Jewish Scripture (termed Old Testament by Christians) gives instances in which God abandoned and replaced disobedient kings, such as Saul (1Sam. 15:10-23", and rebuked others, such as David (2Sam. 12:1-25). Bidmos (2012) also cites the extent to which God abhors injustice in the Qur'an thus: "Do not let hatred of a people prevent you from being just. Be just; that is nearer to righteousness (Q5:8)." That emphasizes that pristine Islam does not compromise on justice, and so, an unjustly treated person or people can seek redress even physically, as the Prophet himself did in respect of the Meccans who pushed him to flee his native land. Thus, those who are misruling Nigeria deserve no respite, irrespective of their religious profession, unless the ordinary citizens who are the victims succumb to religious bigotry. Freedom House (2012) notes that:

The Arab Spring of 2011 launched an era of sweeping political changes in the countries of the Middle East and North Africa, which has historically been the least free region in the world. The fall of longtime leaders and the people's rising demands for a stronger voice in their own governance have brought new opportunities for reform and democratic transition in countries otherwise marked by severe abuses of almost all fundamental political rights and civil liberties.

The nomenclature, Arab Spring, as noted in Wikipedia (2012), is a term given to the Arab Revolution, written in Arabic as: العربية الثورات, al-Thawrāt al-Arabiyyah. It has issued in a "revolutionary wave of demonstrations and protests in the Arab world, since its emergence on 18 December 2010". It has been bloody, leading to heavy loss of lives and property, but has also resulted in change of government in several Arab countries, including "Tunisia, Egypt, Libya, and Yemen; civil uprisings have erupted in Bahrain and Syria; major protests have broken out in Algeria, Iraq, Jordan, Kuwait, Morocco, and Sudan; and minor protests have occurred in Lebanon, Mauritania, Oman, Saudi Arabia, Djibouti, and Western Sahara" (Wikipedia 2012). If that is the situation of things in the Arab world whence Islam came into Nigeria, Nigerian Muslims who mean well politico-economically cannot claim that violent revolution is un-Islamic; not when there is no other possible means.

Indeed, violent actions, reactions and wars are not strange in Islamic history, as in most human histories. Apart from Muhammad's war against the Meccans who drove him from his home country, the near innumerable Jihads testify abundantly to the fact of war as inclusive in the Islamic approach to life. One would think that life is also about war, since, at times, there may be no peace unless a war is fought; or a strong objection or protest is made. Many of the Arab Spring protesters encountered violent resistance, and the demonstrators faced counter demonstrations from pro-government demonstrators and at times pro-government militias, but insisted Ash-sha 'b yurìd isqāt an-nizām -"the people want to bring down the regime"- (Wikipedia 2012). When civil resistance tactics, such as simple protest or objection, strikes, demonstrations, marches, and rallies, failed, it got to a point the people damned the consequences of a revolutionary battle or a full scale war, to secure social equity and justice. Of course, able revolutionary leaders who can mobilise, think, plan, and strategise for the mass of ordinary people are a sine qua non, but that shouldn't be too much of a problem if the populace is well sensitised to the possibility, and indeed, necessity of a revolution in the first instance, which is the primary endeavour of this paper.

\section{Conclusion}

This study has addressed the issue of how both Christianity and Islam support war against injustice. It searched and found evidence of approval for confrontational revolution in the life and teaching of Jesus and Muhammad, respectively, which can unite ordinary Christians and Muslims in Nigeria to fight the yoke of social injustice that is retarding the country's progress. One is convinced that mass impoverishment will persist as long as ordinary Christians and Muslims don't unite against it, revolutionarily, as happened in some other progressive climes. Obviously, the perpetrators who collude in the act of misappropriation of public wealth in Nigeria are some powerful Christian and Muslim politicians who are dominating the land. Poverty, hunger, and misery don't distinguish between Christians and Muslims, and those who are colluding in the mass exploitation of ordinary Nigerians are some Christians and Muslims. Unless the mass of ordinary Christians and Muslims unite to confront their exploiters who use religion as a means of divide and rule, paradigm may never shift in favour of the impoverished majority. One prays and hopes that talented revolutionary leaders will emerge to lead the people, and that the people will cooperate in the effort to free the country from imperialism and neocolonialism that is breeding mass poverty which cuts across religion and ethnic nationality. As observed in the body of this study, the neo-colonialists must be confronted in the same way the African nationalists fought colonialism, without allowing any religious sentiment to stand on their way; the focus should be social equity, justice, and financial accountability. 


\section{References}

[1] Adeniyi, M.O. (2004). 'An Islamic Approach for Sustaining Democracy in Nigeria', In Islam and Democracy in Nigeria: Proceedings of the 20th National Conference of the Nigerian Association of Teachers of Arabic and Islamic Studies (NATAIS), held at the University of Ibadan, 3-7 October, 2001, (pp. 47-54)

[2] Appadorai, A. (2004). The Substance of Politics. New Delhi: Oxford University Press.

[3] Baker, J. P. (1998). "Love", in New Dictionary of Theology, edited by Ferguson, Sinclair B, Wright David F. And Packer, J.I. Leicester: Inter-Varsity Press.

[4] Bidmos, M. A. (2006). Inter-Religious Dialogue: The Nigerian Experience. Abuja: Panaf Publishing, Inc.

[5] Boer, Harry R. 1976. A Short History of the Church. Ibadan: DayStar.

[6] Casalis, G. (1981). Interview with Teofilo Cabestrero, in Faith: Conversations with Contemporary Theologians: ladislaus Boros, georges Casalis, Jose Comblin, Enrique D. Dussel, Segundo

[7] Galilea, Giulio Girardi, Jose Maria Gonzalez Ruiz, Gustavo Gutierrez, Hans Kung, Jurgen Moltmann, Karl Rahner, Joseph Ratzinger, Edward Schillebeeckx, Juan Luis Segundo, Jean Marie Tillard, edited by Cabestrero, T. New York: Orbis Books, pp. 2132.

[8] Clouse, R. G. (1998). "Love and Peace" ", in New Dictionary of Theology, edited by Ferguson, Sinclair B, Wright David F. and Packer, J.I. Leicester: Inter-Varsity Press.

[9] Craghan, John F. 1994. "Pacifism", in The Modern Catholic Encyclopedia, edited by Glazier, M. and Hellwig, M. K. Minnesota: The Liturgical Press.

[10] Crossan, J. D. (2007). God and Empire: Jesus Against Rome, Then and Now. HarperSanFrancisco.

[11] Fajana, A. (1976). Nigeria and Her Neighbours. Lagos: African University Press.

[12] Freedom House. (2012). "The Arab Spring”. http://www.freedomhouse.org/article/iran\%E2\%80\%99s-abuse-its-own-peoplehumanitarian-catastrophe

[13] Gutierrez, G. (1981). Interview with Teofilo Cabestrero, in Faith: Conversations with Contemporary

[14] Theologians: ladislaus Boros, georges Casalis, Jose Comblin, Enrique D. Dussel, Segundo

[15] Galilea, Giulio Girardi, Jose Maria Gonzalez Ruiz, Gustavo Gutierrez, Hans Kung, Jurgen

[16] Moltmann, Karl Rahner, Joseph Ratzinger, Edward Schillebeeckx, Juan Luis Segundo, Jean Marie Tillard, edited by Cabestrero, T. New York: Orbis Books, pp. 95-105.

[17] Konijn, S. (1973). The Bridge From Old to New in Christian Belief. London: Geoffrey Chapman.

[18] Norman, S. (2004). "Theocracy", in Holman Illustrated Bible Dictionary, edited by Brand, C, Draper, C., and England, A. Tennessee: Holman Reference.

[19] Odumuyiwa, E. Ade. (2001). A Religious but Criminal Society - Any Remedy? $19^{\text {th }}$ Inaugural Lecture, Olabisi Onabanjo University, Ago-Iwoye.

[20] O’Hear, A. and Groves, J. (1994). Introducing Jesus. Cambridge: Icon Books Ltd.

[21] Renwick, A. M. and Harman, A. M. 2002. The Story of the Church. Leicester: Inter-Varsity Press.

[22] Ruiz, J. M. G. (1981). Interview with Teofilo Cabestrero, in Faith: Conversations with Contemporary Theologians: ladislaus Boros, georges Casalis, Jose Comblin, Enrique D. Dussel, Segundo

[23] Galilea, Giulio Girardi, Jose Maria Gonzalez Ruiz, Gustavo Gutierrez, Hans Kung, Jurgen

[24] Moltmann, Karl Rahner, Joseph Ratzinger, Edward Schillebeeckx, Juan Luis Segundo, Jean Marie Tillard, edited by Cabestrero, T. New York: Orbis Books, pp. 78-94.

[25] Sabine, G. H. and Thorson, T. L. (1973). A History of Political Theory. New Delhi: Oxford \& IBH Publishing Co. PVT. Ltd

[26] Schreck, A. (1987). The Compact History of the Catholic Church. Michigan: Servant Books.

[27] Schillebeeckx, E. (1981). Interview with Teofilo Cabestrero, in Faith: Conversations with Contemporary

[28] Theologians: ladislaus Boros, georges Casalis, Jose Comblin, Enrique D. Dussel, Segundo

[29] Galilea, Giulio Girardi, Jose Maria Gonzalez Ruiz, Gustavo Gutierrez, Hans Kung, Jurgen

[30] Moltmann, Karl Rahner, Joseph Ratzinger, Edward Schillebeeckx, Juan Luis Segundo, Jean Marie Tillard, edited by Cabestrero, T. New York: Orbis Books, pp. 158-171.

[31] Smart, N. 1981. The Religious Experience of Mankind. Glasgow: Fount Paperbacks.

[32] Smith, J. R. and Smith, L. B. (1980). Essentials of World History. New York: Barron's Educational Series.

[33] Smith, H. (1991). The World's Religions. HarperSanFrancisco.

[34] Tasie, G.O. M. (2003). African Culture, Modern Science and Religious Thought. In P. A. Dopamu, S.O. Oyewole, R. A. Akanmidu, M. A. Akanji, R. O. Ogunade, R. D. Abubakre, I. O. Oloyede, and B. Lawal (Eds.), African Culture, Modern Science and Religious Thought. University of Ilorin, African Centre for Religions and Science, pp. 3-13.

[35] Wikipedia. 2012. "The Arab Spring”. http://en.wikipedia.org/wiki/Arab_Spring.

[36] Yahya, M. T. (1984). "Jihad and Peaceful Co-existence: Contrasts or Causalities", in Religion and Unity in Nigeria, edited by Mala, S. B. and Oseni, Z. I. Nigerian Association for the Study of Religions, pp.40-55. 